\title{
Research of Knowledge and Attitudes of Patients with Diabetic Foot Ulcer Regarding Foot Care
}

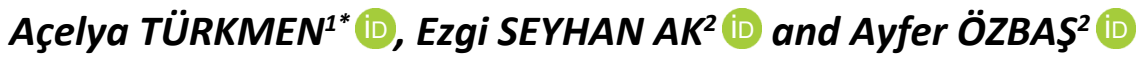 \\ ${ }^{1}$ Department of Nursing, Surgical Nursing, Faculty of Health Sciences, Cukurova University, Adana, Turkey \\ ${ }^{2}$ Department of Surgical Nursing, Faculty of Nursing, Istanbul University-Cerrahpaşa Florence Nightingale, \\ Istanbul, Turkey
}

*Corresponding author: Res. Asis. Açelya Türkmen, PhD, Department of Nursing, Surgical Nursing, Faculty of Health Sciences, Cukurova University, Adana, Turkey, Tel: 05424383439

\begin{abstract}
Background: This study is conducted to analyze the diabetic foot ulcer patients' knowledge and attitudes regarding foot care.

Methods: Patients diagnosed with type 2 diabetes in the diabetic foot service of a university hospital in Istanbul created the population of this descriptive study. The sample consisted of 73 patients determined by power analysis (95\%) and simple random sampling method. A survey form which is consists of 37 questions and created by the researcher is used as the data collection tool. Before beginning the study, the ethics committee approval is obtained. Results are evaluated at a $95 \%$ confidence interval and the level of significance is accepted as a p-value of $<0.05$.
\end{abstract}

Results: It is determined that $67.1 \%(n=49)$ of the patients participating in the study are male, $61.6 \%(n=45)$ are married, $95.9 \%(n=70)$ are over 45 -years-old, $63 \%(n=46)$ are primary school graduate, and $23.9 \%(n=17)$ had participated in the diabetes education program. In terms of the frequency of doing leg and foot gymnastics, applying cream, walking, shoe control, performing diabetes gymnastics, and selecting socks, there is a statistically significant difference between the patients who engaged in the diabetes education program and the patients who do not $(p=0.00<0.05)$.

Conclusion: It is determined that the majority of patients do not receive training on diabetic foot and do not have a positive attitude about performing certain applications, according to the findings of the study. Concordantly, in order to eliminate the patients' knowledge deficits, it may be suggested that comprehensive and planned training should be provided, the results of the given training should be observed, and the training should be repeated at regular intervals by the nurses, who have a significant role in developing self-care abilities and positive behavioral change in individuals with diabetes.

\section{Keywords}

Diabetic foot, Patient, Knowledge, Attitude, Nurse

\section{Introduction}

Diabetes mellitus (DM) is a metabolic disease that develops due to insulin deficiency, insulin resistance, or a combination of the two. Diabetes mellitus is becoming more common with each passing year, with the number of people living with diabetes expected to rise 1.5 fold from 463 million in 2019 to 700 million in 2045. Diabetic foot ulcers, one of the most serious complications of diabetes, macrovascular disease and microvascular damage accompanied by neuropathy and ischemic problems, which facilitates the development of infection, ulcer and gangrene and eventually causes morbidity and mortality, is a difficult, long and costly health problem $[1,2]$. The global prevalence of diabetic foot ulcers has been reported to be $6.3 \%$ [3]. Individuals' quality of life suffers as a result of complications caused by diabetic foot ulcers, as well as a rise in mortality and a physical, psychological, and economic burden $[2,4,5]$.

The diabetic foot ulcer is a major health issue that necessitates a multidisciplinary approach and has a negative impact on the lives of individuals. The principles of diabetic foot ulcer prevention and treatment include determining the foot at risk, routine foot supervision, patient, family, and healthcare professional education, adequate shoe selection, and treatment of early signs of foot ulcers [6].

Citation: TÜRKMEN A, Ezgi SEYHAN AK, ÖZBAŞ A (2021) Research of Knowledge and Attitudes of Patients with Diabetic Foot Ulcer Regarding Foot Care. Int J Diabetes Clin Res 8:144. doi.org/10.23937/23773634/1410144

Accepted: June 12, 2021: Published: June 14, 2021

Copyright: (C) 2021 TÜRKMEN A, et al. This is an open-access article distributed under the terms of the Creative Commons Attribution License, which permits unrestricted use, distribution, and reproduction in any medium, provided the original author and source are credited. 
The attitudes of diabetic patients towards foot care significantly reduce the risk of ulcer development. Checking the shoes worn on a regular basis, selecting the right shoes, nail clipping, and daily foot control are among the foot care behaviors that should be performed. Besides, while knowledge is necessary for proper foot care, a lack of knowledge precipitates to the development of diabetic foot ulcers $[7,8]$.

Over the last two decades, research has centered on diabetic patients' foot care knowledge, attitudes, and practices with the aim of recognizing obstacles to seeking medical care, enhancing self-care, and making lifestyle changes $[2,9,10]$.

Diabetic foot ulcers are a disorder that can be avoided to a great degree by taking the necessary precautions [11,12]. Diabetic foot ulcers are associated with knowledge and care attitudes. Therefore, diabetic foot ulcers can be avoided by improving the knowledge level of patients about foot care $[13,14]$. Diabetic patients, according to studies, have an insufficient attitude about foot care and a lack of knowledge about it [2,14-16]. $58 \%$ of the patients are reported to have little knowledge about foot care in another study, and $61.8 \%$ have a more negative attitude about diabetic foot care [16]. In a study conducted in India, it is observed that very few patients $(12.5 \%)$ underwent professional foot care training and had little awareness of foot care [15]. In another study, $82.7 \%$ of the patients are reported to have a good level of foot care knowledge, however only $22.4 \%$ of them had good foot care practices [17].

Studies have improved diabetic foot care practice by supporting higher level of knowledge and positive attitude towards diabetic foot care $[18,19]$. In light of these findings, this study's aim is to analyze the knowledge and attitudes of diabetic foot ulcer patients about foot care, as well as to contribute to the literature with the findings.

\section{Methods}

\section{Type of the study}

This study is conducted to analyze the diabetic foot ulcer patients' knowledge and attitudes regarding foot care.

\section{Population and sample}

Patients with type 2 diabetes who are diagnosed with diabetic foot in a university hospital in Istanbul province between March and December 2017 created the study's population. The sample of the study consisted of patients within the universe who gave consent to participate in the study after being informed by explaining the purpose of the study and who have met the study criteria. The sample size for the analysis is calculated using the 3.1 version of the $\mathrm{G}^{*}$ Power program, and the appropriate sample size is achieved using the chi-square goodness of fit test. In order to find out whether there is a difference in the attitudes and knowledge levels of diabetic patients regarding foot care, the sample size which is determined for $(2-1)^{*}(2-1) 1$ degree of freedom and Cohen's effect size of $d=0.33$ (since there are people who receive education and those who do not) at $95 \%$ confidence level ( $\alpha=0.05$ and two-way), 0.80 test power (1- -6$)$ is calculated as 73 persons. A pilot study was conducted with 10 patients. Patients in the pilot study were not included in the sampling. Patients with type 2 diabetes, diabetic foot ulcers, above the age of 18 who wanted to participate and patients with grade 1-4 ulcers according to Wagner's classification were included in the study. Patients with mental illness, limb amputation and under 18 years of age were excluded from the study.

\section{Data collection}

The questionnaire used in the study is prepared by the researchers in line with the literature [20]. There are a total of 37 questions on the data collection form, which is divided into two parts: 16 questions on demographic characteristics of patients such as age, gender, smoking status, and treatment type in the first part, and 21 questions related to diabetes and diabetic foot care attitude in the second part. Data are collected using the face-to-face interview technique with patients. Face to face interview was conducted by the researcher for 20 minutes.

\section{Ethical considerations}

Permission is obtained from both The Clinical Research Ethics Committee (No: 2017-52635) and the hospital where the study would be performed before beginning the study. After giving the patients a clarification about the study, their written and verbal consent are obtained.

\section{Evaluation of data}

All data were analyzed using IBM SPSS Statistics, Version 22.0 (IBM SPSS, Statistical Package for the Social Sciences, Turkey) software. Descriptive statistical methods (mean, median, number, percentage) are used in the evaluation. Chi-square tests are used for comparative analysis and independent samples t-test is used for quantitative comparisons. Results are evaluated at a $95 \%$ confidence interval and the level of significance is accepted as a p-value of $<0.05$.

\section{Results}

It is seen in Table 1 that $32.9 \%(n=24)$ of the participants are female, $67.1 \%(n=49)$ are male, $61.6 \%(n=$ $45)$ are married, $95.9 \%(n=70)$ are over the age of 45 , $63 \%(n=46)$ are primary school graduates, $32.9 \%(n=$ $24)$ are retired, $20.5 \%(n=15)$ were smokers, $67 \%(n=$ 49) are diagnosed with diabetes for more than 6 years, $46.6 \%(n=34)$ used insulin, 90.4\% ( $n=66)$ had ulcer treatment, $79.5 \%(n=58)$ had ulcer surgery. 
Table 1: Distribution of the Descriptive Characteristics of the Patients $(\mathrm{N}=73)$.

\begin{tabular}{|c|c|c|c|}
\hline \multicolumn{2}{|l|}{ Characteristics } & \multirow{2}{*}{$\begin{array}{l}\mathbf{N} \\
24\end{array}$} & \multirow{2}{*}{$\begin{array}{l}\% \\
32.9\end{array}$} \\
\hline Gender & Female & & \\
\hline & Male & 49 & 67.1 \\
\hline \multirow[t]{2}{*}{ Marital Status } & Married & 45 & 61.6 \\
\hline & Single & 28 & 38.3 \\
\hline \multirow[t]{5}{*}{ Age } & $18-24$ & 0 & 0 \\
\hline & $25-31$ & 0 & 0 \\
\hline & $32-38$ & 0 & 0 \\
\hline & $39-45$ & 3 & 4.1 \\
\hline & 45 years and older & 70 & 95.9 \\
\hline \multirow{5}{*}{$\begin{array}{l}\text { Educational } \\
\text { background }\end{array}$} & Illiterate & 5 & 6.8 \\
\hline & Literate & 5 & 6.8 \\
\hline & $\begin{array}{l}\text { Primary school } \\
\text { graduate }\end{array}$ & 46 & 63.0 \\
\hline & $\begin{array}{l}\text { High school } \\
\text { graduate }\end{array}$ & 12 & 16.4 \\
\hline & $\begin{array}{l}\text { Graduated from a } \\
\text { Universty }\end{array}$ & 5 & 6.8 \\
\hline \multirow[t]{5}{*}{ Working condition } & Housewife & 24 & 32.9 \\
\hline & Retired & 24 & 32.9 \\
\hline & Officer & 2 & 2.7 \\
\hline & Worker & 3 & 4.1 \\
\hline & Other & 20 & 27.4 \\
\hline \multirow[t]{2}{*}{ Smoking } & Yes & 15 & 20.5 \\
\hline & No & 58 & 79.5 \\
\hline \multirow{5}{*}{$\begin{array}{l}\text { Year of diabetes } \\
\text { diagnosis }\end{array}$} & Less than 1 year & 8 & 11 \\
\hline & 1 to 5 years & 16 & 21.9 \\
\hline & 6 to 10 years & 12 & 16.4 \\
\hline & 11 to 20 years & 12 & 16.4 \\
\hline & More than 20 years & 25 & 34.2 \\
\hline \multirow{4}{*}{ Diabetes treatment } & Only diet therapy & 1 & 1.4 \\
\hline & $\begin{array}{l}\text { Oral antidiabetic pill } \\
+ \text { insulin }\end{array}$ & 36 & 49.3 \\
\hline & Insülin & 34 & 46.6 \\
\hline & Other & 2 & 2.7 \\
\hline \multirow{2}{*}{$\begin{array}{l}\text { Diabetic Foot ulcer } \\
\text { treatment }\end{array}$} & Yes & 66 & 90.4 \\
\hline & No & 7 & 9.6 \\
\hline \multirow{2}{*}{$\begin{array}{l}\text { Having a foot ulcer } \\
\text { surgery }\end{array}$} & Yes & 58 & 79.5 \\
\hline & No & 15 & 20.5 \\
\hline
\end{tabular}

However, it is seen in Table 2 that $23.3 \%(n=17)$ of the participants engaged in the diabetes education program, $86.3 \%(n=63)$ thought that patients with diabetes had more ulcers than other people, $80.8 \%(n=59)$ thought patients with diabetes who smoked had more ulcers than non-smokers, $94.5 \%$ thought that diabetic patients should regularly perform foot care, $90.4 \%$ thought that diabetic patients' feet might have to be amputated due to injuries.

It is seen that $39.7 \%(n=29)$ of the participants in the study go for a check up once a month, $13.7 \%$ ( $n=$
Table 2: Information Status of Patients Regarding Foot Care $(\mathrm{N}=73)$.

\begin{tabular}{|c|c|c|c|}
\hline Characteristics & & $\mathbf{n}$ & $\%$ \\
\hline Participation in a previous diabetes & Yes & 17 & 23.3 \\
\hline & No & 56 & 76.7 \\
\hline Having more ulcers than other & Yes & 63 & 86.3 \\
\hline & No & 10 & 13.7 \\
\hline Having more ulcers in patients with & Yes & 59 & 80.8 \\
\hline smokers & No & 14 & 19.2 \\
\hline Diabetic patients should take & Yes & 69 & 94.5 \\
\hline regular toot care & No & 4 & 5.5 \\
\hline Diabetic patients' feet may have to & Yes & 66 & 90.4 \\
\hline & No & 7 & 9.6 \\
\hline
\end{tabular}

10) do leg and foot gymnastics every day, $64.4 \%(n=47)$ control the water temperature while washing their feet, $75.3 \%(n=55)$ control the color change of the cracked ulcer, $75.3 \%(n=55)$ use cream, 31.5\% $(n=23)$ perform toenail care once a week, $58.9 \%(n=43)$ cut their toenail straight and not too short, $31.5 \%(n=23)$ walk every day, $65.8 \%(n=48)$ do not walk barefoot, $68.5 \%(n=50)$ do not wear slippers and shoes without socks, $53.4 \%$ (n $=39$ ) control their shoes, $63 \%$ go to the doctor by caring about the ulcer on the foot, $56.2 \%(n=41)$ do not know whether there is diabetes gymnastics or not, $63 \%$ ( $n=$ 46) wear cotton socks that do not tighten their ankles, $41.1 \%(n=30)$ control the soles of their own feet (Table 3).

It is found that there is no statistically significant difference $(p<0.05)$ in knowledge between the patients who have participated in the diabetes education program and those who do not in the study, however, the$r$ is a significant difference in attitudes toward diabetic foot care between the two groups. In terms of the frequency of doing leg and foot gymnastics, applying cream, walking, shoe control, performing diabetes gymnastics, and selecting socks, there is a statistically significant difference between the patients who have engaged in the diabetes education program and the patients who do not $(p=0.00<0.05)$ (Table 4). It is observed that the patients who have engaged in the education program exhibited a more positive attitude about the frequency of doing leg and foot gymnastics, applying cream, walking, shoe control, diabetes gymnastics, and selecting socks.

\section{Discussion}

Although diabetes mellitus occurs more frequently in women, diabetic foot, one of the most common complications of the disease, is more common in men [21]. In the studies of Pourkazemi, et al. [14] and Ahmed, et al. [22], it is observed that the majority of patients with diabetic foot ulcers participating in the study are 
Table 3: Distribution of Patients' Attitudes towards Diabetic Foot Care $(\mathrm{N}=73)$.

\begin{tabular}{|c|c|c|c|}
\hline \multicolumn{2}{|l|}{ Characteristics } & \multirow{2}{*}{\begin{tabular}{|l|}
$\mathbf{n}$ \\
29
\end{tabular}} & \multirow{2}{*}{$\begin{array}{l}\% \\
39.7\end{array}$} \\
\hline \multirow[t]{6}{*}{ Control frequency } & Once a month & & \\
\hline & 1 time in 2 months & 8 & 11 \\
\hline & 1 time in 3 months & 7 & 9.6 \\
\hline & 1 time in 6 months & 7 & 9.6 \\
\hline & 1 time in 12 months & 6 & 8.2 \\
\hline & $\begin{array}{l}\text { Does not go to regular } \\
\text { check-ups }\end{array}$ & 16 & 21.9 \\
\hline \multirow{4}{*}{$\begin{array}{l}\text { Situation of doing leg } \\
\text { and foot gymnastics }\end{array}$} & I never do & 48 & 65.8 \\
\hline & As I wish & 13 & 17.8 \\
\hline & Everyday & 10 & 13.7 \\
\hline & Once a week & 2 & 2.7 \\
\hline \multirow{2}{*}{$\begin{array}{l}\text { Checking the water } \\
\text { temperature }\end{array}$} & Yes & 47 & 64.4 \\
\hline & No & 26 & 35.6 \\
\hline \multirow{2}{*}{$\begin{array}{l}\text { checking the condition } \\
\text { of the ulcer cracks and } \\
\text { discoloration }\end{array}$} & Yes & 55 & 75.3 \\
\hline & No & 18 & 24.7 \\
\hline \multirow[t]{2}{*}{ Use of cream } & Yes & 55 & 75.3 \\
\hline & No & 18 & 24.7 \\
\hline \multirow[t]{2}{*}{ How to warm the foot } & I wear socks & 70 & 95.9 \\
\hline & I warm it with a heater & 3 & 4.1 \\
\hline \multirow[t]{5}{*}{ Toenail care } & Everyday & 2 & 2.7 \\
\hline & Once a week & 23 & 31.5 \\
\hline & 1 time in 15 days & 23 & 31.5 \\
\hline & Once a month & 18 & 24.7 \\
\hline & I never do & 7 & 9.6 \\
\hline \multirow[t]{3}{*}{ Nail cut } & $\begin{array}{l}\text { Straight, I cut it without } \\
\text { being too short }\end{array}$ & 43 & 58.9 \\
\hline & $\begin{array}{l}\text { I cut it on the edge of } \\
\text { the nail with the flesh- } \\
\text { sinking places }\end{array}$ & 19 & 26 \\
\hline & I cut it round, short & 11 & 15.1 \\
\hline \multirow{5}{*}{$\begin{array}{l}\text { The frequency of } \\
\text { walking }\end{array}$} & I never do & 24 & 32.9 \\
\hline & Everyday & 23 & 31.5 \\
\hline & Once in 3-4 days & 12 & 16.4 \\
\hline & Once a week & 9 & 12.3 \\
\hline & Once a month & 5 & 6.8 \\
\hline \multirow[t]{2}{*}{ Barefoot walking status } & Yes & 25 & 34.2 \\
\hline & No & 48 & 65.8 \\
\hline \multirow{2}{*}{$\begin{array}{l}\text { Wear shoes without } \\
\text { socks and slippers } \\
\text { status }\end{array}$} & Yes & 23 & 31.5 \\
\hline & No & 50 & 68.5 \\
\hline \multirow[t]{3}{*}{ Shoe control } & Yes & 39 & 53.4 \\
\hline & No & 17 & 23.3 \\
\hline & Sometimes & 17 & 23.3 \\
\hline \multirow{3}{*}{$\begin{array}{l}\text { Don't care about the } \\
\text { ulcer on the foot }\end{array}$} & I intervene & 23 & 31.5 \\
\hline & I go to the doctor & 46 & 63 \\
\hline & I don't care & 4 & 5.5 \\
\hline \multirow{3}{*}{$\begin{array}{l}\text { Doing diabetes } \\
\text { gymnastics }\end{array}$} & Yes & 18 & 24.7 \\
\hline & No & 14 & 19.2 \\
\hline & I do not know & 41 & 56.2 \\
\hline
\end{tabular}

Choosing socks

\begin{tabular}{|l|l|l|}
\hline $\begin{array}{l}\text { Woolly, does not tighten } \\
\text { the wrists }\end{array}$ & 7 & 9.6 \\
\hline $\begin{array}{l}\text { Cotton, does not tighten } \\
\text { the wrists }\end{array}$ & 46 & 63 \\
\hline $\begin{array}{l}\text { Synthetic, easy to } \\
\text { tighten the ankles }\end{array}$ & 4 & 5.5 \\
\hline None & 16 & 21.9 \\
\hline I use a mirror & 4 & 5.5 \\
\hline I try to look myself & 30 & 41.1 \\
\hline $\begin{array}{l}\text { I get someone in the } \\
\text { family to look }\end{array}$ & 30 & 41.1 \\
\hline $\begin{array}{l}\text { I only show when I go to } \\
\text { the doctor }\end{array}$ & 9 & 12.3 \\
\hline
\end{tabular}

women, while the majority of patients in this study are men. This condition can be explained by the fact that diabetic foot ulcers occur more often in diabetic male patients in the sample due to a lack of routine preventive care behaviors.

Studies show that male gender, smoking, length of ilIness, cardiovascular disease, and poor glycemic control are the main risk factors for the development of diabetic foot ulcers $[3,18]$. In diabetic patients, long-term elevated blood sugar leads to a slew of chronic complications [1]. In their study, Ahmed, et al. [22] have determined that factors such as education and income levels, long diabetes duration, and family history are all effective in the development of diabetic foot ulcers. Eroğlu and Yürügen [1] have found in their study that the majority of patients with diabetic foot ulcers had advanced age and long-term ( $>16$ years) diabetes. It is determined that the majority of the patients in this study also had diabetes for more than 10 years.

Education of diabetic patients is of great importance in preventing and treating diabetic foot ulcers. Knowledge not only aids in the development of a positive attitude but also in making the right decisions about diabetes. Patient behavior directly affects patient consequence [20].

The inadequacy of education programs regarding diabetic foot and the lack of a team approach to the treatment of complex foot problems are among the possible causes of foot complications in diabetic patients $[3,18]$. Enabling diabetic patients to acquire knowledge, attitudes, and skills to achieve individual care, and encouraging them to do so will increase their quality of life and reduce their dependence on others [23]. There are some studies in the literature suggesting that providing individuals with education on diabetic foot leads to improvement in their knowledge, attitudes, and behaviors. In the study conducted by Kafaie [24], s/he reported that diabetic patients' average foot care scores improved after education. In the study conducted by Al-Hariri, et al. [18], they have discovered that the majority of patients received education on diabetic foot and had positive attitudes towards foot care. Ahmed, et 
Table 4: Comparison of Patients' Attitudes According to Their Education Status $(N=73)$.

\begin{tabular}{|c|c|c|c|c|c|c|}
\hline \multirow{3}{*}{ Characteristics } & & \multicolumn{5}{|c|}{ Education status } \\
\hline & & \multicolumn{2}{|c|}{ Yes } & \multicolumn{2}{|l|}{ No } & \multirow{2}{*}{ Test } \\
\hline & & $\mathbf{n}$ & $\%$ & $\mathbf{n}$ & $\%$ & \\
\hline \multirow{4}{*}{$\begin{array}{l}\text { Situation of doing leg and foot } \\
\text { gymnastics }\end{array}$} & I never do & 5 & 29.4 & 43 & 76.8 & \multirow{4}{*}{$\begin{array}{l}{ }^{1} \chi^{2}=16.40 \\
p=0.00\end{array}$} \\
\hline & As I wish & 6 & 35.3 & 7 & 12.5 & \\
\hline & Everyday & 4 & 23.5 & 6 & 10.7 & \\
\hline & Once a week & 2 & 11.8 & 0 & 0 & \\
\hline \multirow[b]{2}{*}{ Checking the water temperature } & Yes & 12 & 70.6 & 35 & 62.5 & \multirow{2}{*}{$\begin{array}{l}{ }^{1} \chi^{2}=0.37 \\
p=0.54\end{array}$} \\
\hline & No & 5 & 29.4 & 21 & 37.5 & \\
\hline \multirow{2}{*}{$\begin{array}{l}\text { Checking for crack wound } \\
\text { discoloration }\end{array}$} & Yes & 15 & 88.2 & 40 & 71.4 & \multirow{2}{*}{$\begin{array}{l}{ }^{1} \chi^{2}=1.98 \\
p=0.20\end{array}$} \\
\hline & No & 2 & 11.8 & 16 & 28.6 & \\
\hline \multirow[t]{2}{*}{ Cream usage status } & Yes & 17 & 100 & 38 & 67.9 & \multirow{2}{*}{$\begin{array}{l}{ }^{2} \chi^{2}=7.25 \\
p=0.00\end{array}$} \\
\hline & No & 0 & 0 & 18 & 32.1 & \\
\hline \multirow[t]{5}{*}{ Toenail care } & Everyday & 1 & 5.9 & 1 & 1.8 & \multirow{5}{*}{$\begin{array}{l}{ }^{1} \chi^{2}=7.04 \\
p=0.13\end{array}$} \\
\hline & Once a week & 4 & 23.5 & 19 & 33.9 & \\
\hline & 1 time in 15 days & 9 & 52.9 & 14 & 25 & \\
\hline & Once a month & 3 & 17.6 & 15 & 26.8 & \\
\hline & I never do & 0 & 0 & 7 & 12.5 & \\
\hline \multirow[t]{5}{*}{ The frequency of walking } & I never do & 5 & 29.4 & 19 & 33.9 & \multirow{5}{*}{$\begin{array}{l}{ }^{1} \chi^{2}=16.83 \\
p=0.00\end{array}$} \\
\hline & Everyday & 3 & 17.6 & 20 & 35.7 & \\
\hline & Once in 3-4 days & 8 & 47.1 & 4 & 7.1 & \\
\hline & Once a week & 0 & 0 & 9 & 16.1 & \\
\hline & Once a month & 1 & 5.9 & 4 & 7.1 & \\
\hline \multirow[t]{3}{*}{ Shoe control } & Yes & 15 & 88.2 & 24 & 42.9 & \multirow{3}{*}{$\begin{array}{l}{ }^{1} \chi^{2}=11.45 \\
p=0.00\end{array}$} \\
\hline & No & 0 & 0 & 17 & 30.4 & \\
\hline & Sometimes & 2 & 11.8 & 15 & 26.8 & \\
\hline \multirow[t]{3}{*}{ Caring for the ulcer in the foot } & I intervene myself & 2 & 11.8 & 21 & 37.5 & \multirow{3}{*}{$\begin{array}{l}{ }^{1} \chi^{2}=4.06 \\
p=0.13\end{array}$} \\
\hline & I go to the doctor & 14 & 82.4 & 32 & 57.1 & \\
\hline & I don't care & 1 & 5.9 & 3 & 5.4 & \\
\hline \multirow[t]{3}{*}{ Doing diabetes gymnastics } & Yes & 10 & 58.8 & 8 & 14.3 & \multirow{3}{*}{$\begin{array}{l}{ }^{1} \chi^{2}=13.95 \\
p=0.00\end{array}$} \\
\hline & No & 2 & 11.8 & 12 & 21.4 & \\
\hline & I do not know & 5 & 29.4 & 36 & 64.3 & \\
\hline \multirow[t]{4}{*}{ Choosing socks } & $\begin{array}{l}\text { Woolly, does not tighten } \\
\text { the wrists }\end{array}$ & 4 & 23.5 & 3 & 5.4 & \multirow{4}{*}{$\begin{array}{l}{ }^{1} \chi^{2}=11.19 \\
p=0.01\end{array}$} \\
\hline & $\begin{array}{l}\text { Cotton, does not tighten } \\
\text { the wrists }\end{array}$ & 13 & 76.5 & 33 & 58.9 & \\
\hline & $\begin{array}{l}\text { Synthetic, easy to tighten } \\
\text { the ankles }\end{array}$ & 0 & 0 & 4 & 7.1 & \\
\hline & None & 0 & 0 & 16 & 28.6 & \\
\hline
\end{tabular}

${ }^{1} \chi^{2}=$ Pearson's Chi-square Test; ${ }^{2} \chi^{2}=$ Fisher's Exact Test.

al. [22] have found in their study that the knowledge of approximately half of the patients about diabetic foot care is at a good level. In patients with type 2 diabetes, Moradi, et al. [23] have discovered that education enhanced foot care practices and metabolic control. Alshammari, et al. [25] have discovered in their study that the majority of the patients are well-educated, with a good level of knowledge and attitudes. On the other hand, several studies have revealed that diabetic patients' foot care knowledge and practices are inade- quate [14,26-28]. In the study conducted by Işı [21], it is stated that the majority of diabetic patients did not take diabetic foot care education. The majority of the patients in this study do not have diabetic foot care education, however there is no significant difference between the groups that received education on learning and doing certain practices. This situation can be attributed to the fact that the patients who took part in the study had experience with certain applications as a result of their long-term diabetes. 
In both healthy and diabetic individuals, the feet are the most susceptible organs to injury, trauma, and infection. Reduced protective sensation in the feet and toes, slowed blood circulation, dryness and cracks due to a lack of sweating, peripheral vascular disease, and visual impairment all increase the risk [29]. The fact that patients do not have enough education about foot care raises the risk of trauma and foot ulcers in individuals with diabetes. Daily foot cleaning, creaming, shoe control, nail care, and other applications should all be included in an individual's daily foot care routine. Nural and Hintistan [20] have determined in their study that patients' protective attitudes towards foot health are low. In the study of Eroğlu and Yürügen [1], it is found that patients apply cream and have the correct knowledge and practice in selecting socks and shoes. In the study of Kalaycı [30], it is seen that the majority of patients do not use cream and cut their toenails incorrectly, however, they wore cotton socks and placed a high value on shoe preference. Patients who took part in a diabetic foot care education program are observed to have a more positive attitude toward doing leg and foot gymnastics, using cream, walking, shoe control, and choosing socks in this study. Other behaviors such as regulating water temperature, caring for a foot ulcer, and toe-nail care, however, do not show a significant difference between those who are educated and those who are not. The limited content of the education program offered to patients who have had previously been educated could explain these findings. By assessing the patients' lack of knowledge, more comprehensive diabetic foot care educations may be scheduled.

\section{Limitations of the study}

The study's findings are limited to diabetic foot patients that are admitted to a hospital's diabetic foot unit, met the research criteria, and agreed to participate in the study.

\section{Conclusion and Recommendations}

It is determined that the majority of patients do not receive education about diabetic foot and do not have a positive attitude about performing certain applications, according to the findings of the study. Concordantly, in order to eliminate the patients' knowledge deficits, it may be suggested that comprehensive and planned training should be provided, the results of the given training should be observed, and the training should be repeated at regular intervals by the nurses, who have a significant role in developing self-care abilities and positive behavioral change in individuals with diabetes. By minimizing the lack of knowledge that patients have, possible complications can be avoided and patients' life qualities can be enhanced.

\section{Acknowledgements}

We would like to thank all who contributed materially to our study as participating investigators.

\section{Financial Resource}

During this study, any pharmaceutical company that has a direct connection with the subject of the research, a company that provides and/or produces medical tools, equipment and materials, or any commercial company, during the evaluation process of the study, financial and/or or no moral support was received.

\section{Conflict of Interest}

Regarding this study, the authors and/or their family members do not have a scientific and medical committee membership or relationship with their members, consultancy, expertise, working status in any company, shareholding or similar situations that may have a potential conflict of interest.

\section{Production Status of Thesis Study}

The study was not produced from the thesis.

This study was presented as a poster at the $16^{\text {th }} \mathrm{Na}$ tional Nursing Students Congress held in Istanbul on April 26-28, 2017.

\section{Author Contributions}

Working Idea and Design: AT, AÖ; Data Collection and Literature Review: AT, Analysis and Interpretation of Data: AT, ESA,; Preparation of Manuscript: AT, ESA, Approval for Final Issue: AT, ESA, AÖ.

\section{References}

1. Eroğlu $P$, Yürügen B (2020) Knowledge levels of individuals with type 2 diabetes on foot care. Journal of Human Sciences 17: 700-709.

2. Hanley G, Chiou PY, Liu CY, Chen HM, Pfeiffer S (2020) Foot care knowledge, attitudes and practices among patients with diabetic foot and amputation in St. Kitts and Nevis. International Wound Journal 17: 1142-1152.

3. Zhang P, Lu J, Jing Y, Tang S, Zhu D, et al. (2017) Global epidemiology of diabetic foot ulceration: A systematic review and meta-analysis. Annals of medicine 49: 106-116.

4. Al-Rubeaan K, Al Derwish M, Ouizi S, Youssef AM, Subhani SN, et al. (2015) Diabetic foot complications and their risk factors from a large retrospective cohort study. PLoS One 10: e0124446.

5. Hoban C, Sareen J, Henriksen CA, Kuzyk L, Embil JM, et al. (2015) Mental health issues associated with foot complications of diabetes mellitus. Foot Ankle Surg 21: 49-55.

6. Schaper NC, Van Netten JJ, Apelqvist J, Lipsky BA, Bakker $\mathrm{K}$, et al. (2016) Prevention and management of foot problems in diabetes: A Summary guidance for daily practice 2015, based on the IWGDF guidance documents. Diabetes Metabolism Res Rev 32: 7-15.

7. Bohorquez Robles R, Compeán Ortiz LG, González Quirarte $\mathrm{NH}$, Berry DC, Aguilera Pérez P, et al. (2017) Knowledge and practices of diabetes foot care and risk of developing foot ulcers in México may have implications for patients of Méxican heritage living in the US. Diabetes Educ 43: 297303.

8. Bonner T, Foster M, Spears-Lanoix E (2016) Type 2 diabetes-related foot care knowledge and foot self-care practice 
interventions in the United States: A systematic review of the literature. Diabetic Foot Ankle 7: 29758.

9. Beiranvand S, Fayazi S, Asadizaker M (2015) Effect of educational programs on the knowledge, attitude, and practice of foot care in patients with diabetes. Jundishapur Journal of Chronic Disease Care 4: e26540.

10. Mustafa A, lqbal M, Parvez MA (2017) Assessment of knowledge, attitude and practices of diabetics regarding their foot care. Annals of Punjab Medical College (APMC) 11: $43-47$.

11. Bus SA, van Netten JJ (2016) A shift in priority in diabetic foot care and research: $75 \%$ of foot ulcers are preventable. Diabetes Metab Res Rev 32: 195-200.

12. Syed F, Arif MA, Afzal M, Niazi R, Ramzan A, et al. (2019) Foot-care behaviour amongst diabetic patients attending a federal care hospital in Pakistan. J Pak Med Assoc 69: 5863.

13. Haq NU, Durrani $P$, Nasim A, Riaz S (2017) Assessment of knowledge and practice of diabetes mellitus patients regarding foot care in Tertiary Care Hospitals in Quetta, Pakistan. Specialty J Med Res Health Sci 2: 35-43.

14. Pourkazemi A, Ghanbari A, Khojamli M, Balo H, Hemmati $\mathrm{H}$, et al. (2020) Diabetic foot care: Knowledge and practice. BMC Endocrine Disorders 20: 40

15. Kishore S, Upadhyay AD, Jyotsna VP (2015) Awareness of foot care among patients with diabetes attending a tertiary care hospital. Natl Med J India 28: 122-125.

16. Muhammad-Lutfi AR, Zaraihah MR, Anuar-Ramdhan IM (2014) Knowledge and practice of diabetic foot care in an in- patient setting at a Tertiary Medical Center. Malays Orthop J 8: 22-26.

17. Magbanua E, Lim-Alba R (2017) Knowledge and practice of diabetic foot care in patients with diabetes at Chinese $\mathrm{Ge}$ neral Hospital and Medical Center. J ASEAN Fed Endocr Soc 32: 123-131.

18. Al-Hariri MT, Al-Enazi AS, Alshammari DM, Bahamdan AS, Al-Khtani SM, et al. (2017) Descriptive study on the knowledge, attitudes and practices regarding the diabetic foot. $\mathrm{J}$ Taibah Univ Med Sci 12: 492-496.

19. Policarpo NDS, Moura JRA, Melo Júnior EBD, Almeida PCD, Macêdo SFD, et al. (2014) Knowledge, attitudes and practices for the prevention of diabetic foot. Rev Gaucha Enferm 35: 36-42.
20. Nural N, Hintistan S (2015) Examining the knowledge and attitudes of diabetic patients regarding foot care. Anatolian Journal of Nursing and Health Sciences 18: 116-124.

21. Işı G (2018) Determining the risk factors affecting the development of diabetic foot disease and examining the relationship between treatment compliance and diabetic foot disease. Health Sciences University Bursa Yüksek İhtisas Training and Research Hospital.

22. Ahmed SA, Badi S, Tahir $\mathrm{H}$, Ahmed MH, Almobarak AO (2019) Knowledge and practice of diabetic foot care in Sudan: A cross sectional survey. Diabetes Metab Syndr 13: 2431-2435.

23. Moradi A, Alavi SM, Salimi M, Nouhjah S, Shahvali EA (2019) The effect of short message service (SMS) on knowledge and preventive behaviors of diabetic foot ulcer in patients with diabetes type 2. Diabetes Metab Syndr 13: $1255-1260$.

24. Kafaie P, Noorbala MT, Soheilikhah S, Rashidi M (2012) Evaluation of patients' education on foot self-care status in diabetic patients. Iran Red Crescent Med J 14: 829-832.

25. Alshammari ZJ, Alsaid LA, Parameaswari PJ, Alzahrani AA (2019) Attitude and knowledge about foot care among diabetic patients in Riyadh, Saudi Arabia. J Family Med Prim Care 8: 2089-2094

26. Kheir N, Greer W, Yousif A, Al Geed H, Al Okkah R (2011) Knowledge, attitude and practices of Qatari patients with type 2 diabetes mellitus. Int J Pharm Pract 19: 185-191.

27. Hamidah H, Santhna LP, Ruth Packiavathy RD, Suraya AM, Yap WC, et al. (2012) Foot care strategy for the newly diagnosed DM Type 2 patients with low educational and socio-economic background: A step towards future. Clin Ter 163: 473-478.

28. Desalu OO, Salawu FK, Jimoh AK, Adekoya AO, Busari OA, et al. (2011) Diabetic foot care: Self reported knowledge and practice among patients attending three tertiary hospital in Nigeria. Ghana Med J 45: 60-65.

29. Kır Biçer E (2017) Patient education for the prevention of diabetic foot wounds. Curre Res Diabetes Obes $\mathrm{J} 1$ : 555569 .

30. Kalaycı Ö (2016) Evaluation of knowledge, attitude and behavior of diabetic patients about foot care and diabetic foot. Department of Public Health, Institute of Health Sciences, Bülent Ecevit University, Turkey. 